\title{
'Unclear' initial delineation of property boundaries and the third Coase Theorem
}

\author{
Lawrence W.C. LAI*, K.W. CHAU* and Frank T. LORNE** \\ * Roand Coase Centre for Property Rights Research, \\ The University of Hong Kong \\ ** New York Institute of Technology, Vancouver
}

Revise 1 May 2015

The is a preprint version of a paper accepted for publication in LAND USE POLICY

\section{Suggested Citation:}

Lai, Lawrence W.C., Chau, K.W. and Lorne, Frank T. (2015). 'Unclear' initial delineation of property boundaries and the third Coase Theorem. Land Use Policy, 47, 274-281 


\title{
'Unclear' initial delineation of property boundaries and the third Coase Theorem
}

\author{
Lai, Lawrence W.C.* Chau, K.W.* and Lorne, Frank T.** \\ * Roand Coase Centre for Property Rights Research, The University of Hong Kong \\ ** New York Institute of Technology, Vancouver
}

Keywords: Coase Theorem, land boundary, land surveying, land reform, Austrian economics

\begin{abstract}
This interdisciplinary study, which references previous research on the evolution of land law and real world examples of land market operating with unclear property boundaries, demonstrates that Ronald Coase's argument that delimitation of property rights is a prelude to market transaction applies to urban development, in which certitude in initial property boundaries in geodetic terms is not overriding. It explains why even a powerful landlord can be unsure of and do not even want to know the boundaries of the land of his/her tenants and why this mapping limitation in itself does not inhibit market transactions. When land is treated as an input for a chattel that is no longer fixed to land, area measurement is more important than boundary-fixing. When land becomes valued for its location and fixtures (i.e., as real estate), precise boundary delineations and disputes over the precision of cadastral surveys emerge.
\end{abstract}

Boundary disputes are a particularly painful form of litigation. Feelings run high and disproportionate amounts of money are spent. Claims to small and valueless pieces of land are pressed with the zeal of Fortinbras' army (Lord Hoffman in Wibberley v. Insley [1999] HL15). 


\section{Introduction}

The geodetic surveying of land boundaries with planimetric accuracy by qualified persons prior to a property transaction and/or development is a prudent modern practice because disputes over land boundaries, if unsettled by private agreement, often end up in court with huge transaction costs implications. Judges, when asked to make a declaration on the accuracy of the boundary, as surveyed by one party, often comment that the costs of judicial solutions to private disputes over property boundaries appear to be disproportional to the stakes in question.

As a land boundary is an intrinsic dimension of real property (Lai 2015), a clear delineation of a property's boundaries would be a standard neo-institutional economic, if not also legal, prescription for the efficient use and exchange of private property rights over land, according to the First and Second Coase Theorems, which were named after Nobel prize winner Ronald Harry Coase by his colleague George Stigler. Researchers such as Ekbäck (2009), Dawkins (2012), Kreiken and Koepsell (2013), and Havel (2014), who considered the Coase Theorem, stressed that the necessity of modern cadastral surveys and/or cadasters for land property transactions all use the (corollary of the) First Coase Theorem in an implicit context of modern real estate dealings. "Clearly defined" boundaries were taken for granted to mean "fully geodetically-defined" boundaries as essential dimensions of private property rights. In this light, a remark in Harold Demsetz's recent (2011: p.10) comment on the Coasian analysis that less than 100 percent clearly-defined property rights is good for efficiency in "a reasonably described decentralized economic system that puts control of resources into private hands" (Demsetz 2011: p. 11) is rather unorthodox. This paper should shed light on the taken for granted institutional promotion of cadastral surveys as the norm for rapidly developing regions (Li 2012; Havel 2014), which keeps the tradition and ideology of cadastral mapping by European colonists in the Americas, Africa, and Asia (Kain and Baigent 1992; Blomley 2003). Such a view has been projected backwards by Yoo and Steckel (2010) to Korea and Taiwan under Japanese rule to scrutinize the "dual" land system in China. As will be revealed, this work is in line with the works of American surveyor scholar Kent (1988) and Austrian researcher Navratil (2009). Kent explained that the degree of planimetric accuracy of cadasters depends on the purpose: fiscal, legal, or multi-purpose. For fiscal (taxation) purposes, unlike the case of legal cadasters, such accuracy is secondary to the primary one for identifying the person responsible for paying taxes. Navratil (2009) presented as possibility distributions the quality or degree of positional accuracy of cadastral surveys in terms of technology, legal requirements, and user needs for "boundary" or "spatial reference" over time. In a nutshell, science, institutional arrangements, and markets are 
all relevant factors in boundary delineation calling for an interdisciplinary examination of basic surveying, law, and economics.

Under the "First Coase Theorem" or the "Invariant Theorem," invented by Nobel laureate George Stigler after a land use conflict story in Coase (1960) and accepted by Coase (1988), when there are clearly defined property rights and zero transaction costs, institutional designs do not affect resource allocation. The "Second," or "Optimality", theorem predicts that given the same assumptions, resource use is always Paretian-efficient. The "Third" Coase Theorem was identified by Cheung (1990), derived from Coase (1959: p.27), and also accepted by Coase (1988: p.158). It states that "the delimitation of rights is an essential prelude to market transactions" Coase (1988: p.158). This "Third" theorem is far more versatile than the "First" and more liberal than Hayek's (1944) understanding that a market economy requires the rule of law in the fullest sense.

This paper shows that Demsetz's (2011; p.10) proposition is not far from the "Third Coase Theorem," which Demsetz treated as more useful than the First or Second Coase Theorem (2011: 6 ), for which there are some real world examples indicating why mapping requirements are different under different constitutional backgrounds. "The delimitation of rights" as a bundle is less demanding than "clearly defined property rights," not to mention "fully defined property rights," as otherwise the assumption of zero transaction costs would be redundant, as argued by Cheung (1990). Lai (2007) argued that in Coase's (1960) land use conflict story, the meaning of clearly-defined property rights is limited to a clear delineation of the initial common property boundary of two plots of adjoining land. The thesis of this paper is that when the cost of enforcement is high, less than fully defined, but sufficiently clear, property rights can still be efficient. This converts Demsetz's (2011) understanding of Coase, mentioned above, into a form of the Third Coase Theorem. After all that property rights need to be "clearly defined" needs not be "fully defined". As we shall see, in Imperial Chinese farm land renting, certitude in cadastral details up to geodetic surveying standards land was not essential for boundary identification under a land tax quota system.

Disputes regarding land boundaries can be the cause or effect of the "ambiguous property rights" (Lai and Lorne 2014a), which itself is a function of the available technology and governance. A jointly-appointed team of experts, in this case the professional land surveyor, can help resolve de facto ambiguities, as in the instances of famous settlements of international land boundary disputes such as between Chile and Argentina (Rushworth and Smith 1968). However, an expert is less important than a judge in a dispute over de 
jure ambiguities, as in the case of Palma Island, which involved a dispute between the Netherlands and the U.S. (League of Nations 1928).

In any event, whether a land boundary is ultimately a technical, or rather a legal, issue, depends. In a Canadian case, Black v. Norris and Registrar General of Land Titles, the following statement by Minister Logan in the Hansard, which recorded the debate before the passing of the Land Titles Act, stated:

Madam Chairman, I should explain that this (a title guarantee system) is not a guarantee of boundaries, it is a guarantee of title to the land. If, per chance, a boundary dispute arises at the present time, it has to be determined through the normal legal process. Consideration was given to guaranteeing boundaries, but it was found after new investigation that it would be far too expensive at this time. We hope that in a period of 20 or 25 years, those matters will correct themselves (as cited in de Rijcke 2013a: p.36 (Brackets added)).

The message was: there is no legal provision for a guarantee of title to be accompanied by a guarantee of boundaries.

In Hong Kong, in an action of adverse possession in which the role of the expert surveyor was at issue, the judge explained:

...in a case dealing with adverse possession, in most instances, the role of a surveying expert is only limited to assist the court to define the boundaries of the land in dispute and in comparing the usage of the land over the years during the disputed period of time by looking at evidence like lot index plans, survey sheets, aerial photos and other documentary evidence. The ultimate question of whether the person claiming adverse possession has been in occupation is a fact alone and usually has to be established by the claimant in calling factual witnesses (Yip Kwok Sun v. Poly-style Limited [2013]).

In any case, the land surveyor's role is to serve the court, not parties (de Rijcke 2013b).

Note that the land surveyor's functions are a "retracement of established boundaries, and performing work preliminary to the establishment of new boundaries" (Butts, 2006, pp.vii-viii, italics authors') rather than determining boundaries, which is more than a scientific matter. The court always has the final say but, after obtaining the best information from each party, may still be unable to find the precise alignment of the boundaries, as in Lam Pak Kau v. Yu Yuet Fat [1999] CACV 205/1999. 


\section{Economic theories and legal practices regarding land boundaries}

It may be surprising to many that until recently, neither neo-institutional economists nor lawyers were interested in land boundaries, much less ways to delimit them, as an essential dimension of bundling private property rights to land.

The economist's world shows little concern for land as a spatial entity and, hence, property boundaries. Upon careful analysis, even the most famous land-related models treat land boundaries as merely indirect measures of a quantum of land as an input to an output (such as gold, or an agricultural produce) rather than as "real" (i.e., not "fixed" or "immovable") property, as understood by lawyers. In other words, land is treated as a footloose chattel concept. Umbeck's (1981) model is a case in point. This lack of economist interest in land boundaries may have to do with the observed gradual decline in boundary disputes in the U.S. due to the intermediation of conveyancing professionals and the increasing availability of mapping information over time (Hazard 1989). In any case, there must be many instances in which disputes over boundaries were settled privately by might or negotiation, as they fall into the category of Umbeck, rather than by might or litigation. From a broader perspective, Umbeck's analysis is an application of Coase's (1960) land use conflict story, in which all land boundaries were negotiable and tradable. One great contribution of Coase to economics is to posit the government (the officialdom or the bureaucracy as a special form of firm), the law (the court) and private agreement as alternative means of coordinating resource us by resolving conflict of interests or even maximising joint value output of parties to the conflict. The choice of the means depends on the transaction costs specific to the conflict situation. Indeed, subsequent to Umbeck's (1977a, 1981) works, which flowed from his doctoral dissertation, several writers have pointed out an adoption of a "constitutional/law" setting (for instance, McDowell 2002, Clay and Wright 2005) as more relevant at the time of the California gold rush, in contrast to a "self-enforcing agreement," which Umbeck asserted. La Croix (1992) has a similar stance in describing the gold rush in Victoria. Whereas Umbeck treated land as area, these economists correctly treated land as a tree from which apples (the gold) can be picked rather than as locationally significant real property because that was exactly what it was! The "claims" for "land rights" were defined through mining holes declared by physical objects (wooden stakes) and defended by actual occupations. The locations of these holes or their identification signs, rather than any other spatial dimension, really mattered in mining history. Libecap's (1986) treatise correctly referred to the works of Umbeck (1977a, 1977b) and Hallagan (1978) 
as those that covered the delineation of "access to mineral land" rather than precise boundaries. ${ }^{1}$

Regarding the law, under the rule of law in common law jurisdictions, the court, acting in equity, is the de jure ultimate arbiter of boundary dispute between two landlords.

When two landlords have a dispute over the exact alignment of the common boundary between their properties, they may resolve the dispute violently or peacefully through private agreement by way of an arbiter they appoint or by litigation. When two tenants have a similar dispute, it is reasonable for them to expect the landlord to settle the matter upon request. Failing that, they would go to court to resolve it. Coase's (1988) cryptically entitled The Firm, the Market and the Law. The order firm-market-law, with the last means of transactions notoriously expensive, seems to suggest that the officialdom, or government (as a special kind of firm), can be less costly than the market (as argued in his paper, "The Nature of the Firm" (Coase 1937)), while the market can be cheaper than the court.

When the state is the landlord that sells leasehold interests to lessees, as in the case of Hong Kong, the expectation that it would confirm their exact boundaries is greater, as the certainty of consideration is at the root of land boundary delineations, although it is accepted as law that the court is always the ultimate arbiter of any property boundary dispute whether or not the state is the landlord of all the land. The government, as the landlord, can be reasonably expected to enjoy a relative technical, if not absolute (due to its sovereign power), advantage in GIS collection and dissemination as part and parcel of its theoretical nature as a monopoly of violence to protect the lives and private property of individuals.

However, what happens today is the product of an evolutionary process enabled by technological advances in surveying and mapping. Scholars have rediscovered that the precise mapping of land by qualified land surveyors is required for conveyancing is only a recent legal phenomenon (Pottage 1994). As late as the $19^{\text {th }}$ Century, "certainty" in contracts for selling land was assured by memory consolidated by some written narrative, but the appearance of land surveying has enabled certainty to be rigorously defined by mapping.

That being the case, the absence of precise spatial mapping information with geodetic accuracy, if any, does not appear to be a vital hindrance for land transactions from a

\footnotetext{
${ }^{1}$ In Footnote 6 of his paper, Umbeck (1977a) mentioned the importance of marking boundaries to identify trespassing. However, his model emphasised land units.
} 
historical perspective. One may postulate that this ignorance of the exact boundary of land is only true between land sellers and buyers, as they may contract out some details of their land transactions. However, this is even true of the relationship between a landlord and his/her tenants. The former may not know the true boundaries of the latter because:

(a) there is no such mapping information or a need for it at all;

(b) the previous landlord did not leave any accurate mapping information and the present did not have incentive to survey land with boundary delineation in mind; and

(c) the tenants subdivided their properties without providing the landlord of any accurate mapping information.

None of the three scenarios suggests that there was no certainty over location or the size of the land in any contractual arrangement, as mapping can be substituted by words, as expounded fully by Pottage (1994).

\section{What has happened in the real world?}

The case of Hong Kong, as a part of China interrupted by a century of British colonialisation, is excellent in illustrating the above three examples of the unclear initial delineation of land boundaries, they are covered in the three case studies below in the same, respective order.

The three cases involved different constitutional settings but all under what Demsetz (2011: p.11) described as "a reasonably described decentralized economic system that puts control of resources into private hands." The first case study is the first-ever attempt to apply neo-institutional economic concepts to understand property rights on traditional Chinese farmland, which disappeared after 1949, when the Chinese Communist Party abolished the system and collectivized agricultural land. Cheung's (1969) famous analysis of Taiwan's sharecropping was based on an institutional arrangement that was disturbed during the Japanese occupation period. Clarke's (2014) excellent analysis covered the post-1949 era. Interestingly, while Cheung's analysis was to show that share contract was efficient, the imperial Chinese tenancy was basically one of fixed rent, as examined by Rawski (1972) using discoveries by Professor Fu I-ling during the war years about Fukien Province of China. 
The other two examples were taken from Hong Kong, where the government is the landlord of virtually all land. That the land interests sold are leasehold interests rather than those of fee simple absolute in perpetuity does not mean that they are not private or that the economic system is not decentralised. The essential difference is that leasehold interests have an express pre-specified duration, whereas freehold interests are indefinite, but subject to eminent domain ${ }^{2}$. Hence, the owners of private property rights on land can choose the state or the court in the first instance to handle a boundary dispute. The state itself, however, metamorphosed from a generalist with great legitimacy suitable to serve as an arbiter into a technocratic officialdom that did not readily assume responsibility for specifying for contending lessees the true boundary recognised by her as the landlord. Interestingly, while the USA court often found expert surveyors unreliable (de Rijcke 2013b), land surveyors were often praised by Hong Kong judges, as in Yip Kwok Sun v. Poly-style Limited [2013] HKCU.

Case Study 1: "dual"/"divided" ownership of land in South China from 618-907 AD to before 1949

Although China has a long history of private property and town planning based on a rectilinear grid system with special attention to the north-south axial, it did not have a tradition of farmland transactions accompanied by maps. This stands in sharp contrast to the opening up of the American West using grids as a form of land partitioning (Allen 1991). In fact, Dynastic China possessed the know-how to implement grid layouts, but did not apply its setting-out technology (for instance Hedquist (1975); Rose-Redwood (2004); Swetz (2008); and Brock (2014)), which was as old as, if not older than, the Greek system, for its capital and other key cities to its agricultural hinterland. Chinese maps of the countryside were often products of the arts and only recorded place names and landmarks rather than make scaled graphical representations of the ground features. The Ming Dynasty (1368-1644) carried out a comprehensive cadastral survey of farmland for agricultural tax purposes. Its finished product was the "fish scale atlas". The Manchus, who invaded and took over China from the Ming, did not bother to comprehensively resurvey the conquered country for taxation purposes after they conducted one in 1646 (Elman 2003) and declared all taxes to be frozen to encourage productivity, as well as to avoid rural uprisings. This the Manchu honoured for their entire reign, which ended in 1911. Meanwhile, they relied on obsolete Ming records (Watson 1977; Hase 2013), supplemented by the 1646 cadastral survey, to levy agricultural taxes. Titles to rural land

2 Freely transferrable leasehold interests (obtained by purchase rather than grandfathering) are a form of decentralized private ownership like royalties and patents (with legal time limits). A diagram (Figure 2.5) in Lai (1998: p.29) and a recent paper by Lai and Lorne (2014b) illustrate this point. 
parcels, however, were certain and enforceable at the court of the magistrate, especially when they were in the form of deeds.

A striking feature of rural land ownership in Southern China was wet paddy cultivation, which surprised the Japanese when they annexed and conquered Taiwan in 1895 and found that there was a "vertical" conceptual distinction between the "surface" ("skin," "Ti P'i") of the land and its "bottom" ("bone" /T'i Kwat") (Rawski 1972; Hayes 1977, 2006;

Kamm 1977; Ka 1987). When a landowner leased his land to a group of tenants, the former was entitled to rent from the latter based on his retained ownership of the "bone," but the latter had the complete freedom to use the "skin," subject to some minor conditions. Once leased, the tenants could sub-lease or assign their leases without the landlord's permission. Most landlords were absentees and, hence, only interested in collecting rent punctually, as they had to pay land taxes to the state. As the leases were often perpetual, a de jure separation of the ownership of land rights between the owners and the tenants prevailed. Research by Chinese historians has traced the origins of this dual system back to the Tang Dynasty (618-907 AD) (Palmer 1987).

Transactions on the rights to the land (bones or skins) were evidenced by public ceremonies and deeds, surviving samples of which can be found at the Central Library in Causeway Bay, Hong Kong, and in the excellent archival research by Hase (2013). Hase's work gives evidence of sales and the temporary and reversible alienation (including mortgaging) of rights. In the land transaction documents, although the standard Chinese units of volume measurement (i.e., "shing" and "tau") and area measurement (i.e., the rigid measure, "mau," in which $6.08 \mathrm{mau}=1$ acre) and the more flexible "tau tsung" (i.e., "bushels of seeds") were used. Although Hase (2013: p.31) stated that "all the land within some set of boundaries clearly defined on the ground" was from the deeds he collected, these boundaries were defined by no more than a written description of the rough limits in the four directions (east, south, west, and north). No mapping information or sketch of the fields was appended. Official registration of land by land bone owners involved a survey of the area of land under cultivation and the fixing of the tax but no cadastral maps.

According to Hase (2013), disputes over the property rights to land, as described above, were settled by "public opinion" polls in village meetings, which were typically dominated by older educated males. When this failed, the magistrate, to whom the Chinese people were traditionally averse, would be asked to intervene. It is standard economic prediction that specialist rent collectors and private adjudictors would arise in the absence of effective court or official enforcement. There is ample evidence adduced by Hayes (1977) that land skin rights holders had to provide reception and food to accommodate rent collectors, as in the case of Pui O (p.48), and non-official parties (likely local village elders) 
acted as mediators over disputes - as what happened to Tung Chung in 1775 (p.49). (Inferring from the way in which the Chinese government now returns state seized forest land to the successors of their original owners, witnesses who lived in the village for a long time would have to be relied on ${ }^{3}$.) The focus was on the amount of the agreed-upon rent (which was greater than the imperial tax, for sure). Boundaries, however, remained a very elastic matter on which the landlords did not seem bother with, as the tax rate was frozen by the emperor and no national survey was attempted (Hase 2013, p.34).

This partitioning of rights resulting in the "dual ownership" of the land was efficient, ${ }^{4}$ as it encouraged the perpetual tenants to improve the land so that they could keep the entire surplus gained from it above the fixed rent, usually $3-5 \%$ of the anticipated harvest, while the landlord did not have to bother with controlling land use. It is not true that the owner of the land bone only retained an income right and the occupant of the land skin only had the usage right. The former could also alienate the land bone, although he definitely lost his usage right so long as the skin tenant paid rent. The holder of the skin had the right to use, derive income from, and transfer it.

Note that this interesting contractual arrangement was not much different in spirit, if not also in the terminology, of the "responsibility system" adopted by socialist China during the early 1980 s to allow former cooperative farmers to retain all net profits after paying an agreed-upon sum to the state, which was the landowner. The Chinese Communist Party abolished the system and collectivized China's farmland after it took over the country in 1949. In the process, where the topography allowed, the highly irregular land parcels were combined into and used as much bigger rectilinear fields. The same regularisation process occurred on Hong Kong Island and in Kowloon, New Kowloon, and the new towns in the New Territories in Colonial Hong Kong, although the purpose was to confiscate private land parcels and prepare them for land sales and eventually urban development (Lai 1998). This process reduced the transaction costs of measuring and subdividing/recombining land during the urbanization process.

Was that because the marginal product of the land was zero so that boundary delineation on maps was unnecessary? Surely not. Under dual ownership, the tenant had a great

\footnotetext{
${ }^{3}$ Based on the some preliminary official materials collected from a prospective docotral student of the second author.

${ }^{4}$ Note that Cheung's (1969) famous analysis of Taiwan's sharecropping did not mention any separation of rights into bone and skin. Cheung (1969) clearly explained that his study was on post-war Taiwan, which adopted the Republican Chinese land law in 1945. Such law codes were applied it to the pre-existing Japanese land tenure system (Kinda 1997) with one owner.
} 
incentive to work and an ability to accumulate wealth. This impressed the Japanese colonists when they took over Taiwan (Hayes 1977). ${ }^{5}$ Rawski (1972) explained in great detal how and to what extent the imperial Chinese system "provide a striking illustration which, contrary to expectation, tenenacy did not interfere with the cultivator's incentive to raise productivity." (Rawski 1972: p.19) Ramseyer (2012) showed that Japan's land reforms in her colonies did not increase rice productivity within five years after their implementation, although registered land increased by $215 \%$ in Taiwan and by $80 \%$ in Korea after the survey. While this short period could not measure the long term results of the investments in industrial products, Ramseyer's study on rice is still worth reading. In any event, prior to the arrival of the Japanese, Ho (1968: p.314) found that "extensive un-reporting" of crop yields occurred before the Japanese conducted their cadastral survey. "From 1700 to 1900, cultivated land increased from about 50,000 to 500,000 ha. and population increased from 350,000-400,000 to over 3,000,000" Taiwan under the imperial Chinese system (Ho 1975: p.417). Growth in productivity and area of land opened up for cultivation are good indication of an efficient market.

On the other hand, the landlord had no incentive or need to know about partitions and exchanges or sales of land by tenants. Thus, there was no interest in surveying his/her field for mapping purposes. The deeds that created land skin interests specified the locations and areas of the fields with volume proxies. The main concern was rent. The dual land rights system enabled a division of labour between the owners of land bones who specialised in rent and hence tax collection for the central Imperial government in Peking (Beijing) and the holders of land skins who specialised in innovating in rice culture in specific locations which varied in ecological, geographical and factor and product market conditions. Wild most fields were inland, many were coastal and brackish. The fiscal-economic division of labour signified an information discovery process stressed by Austrian economics. This process was enabled by the lenient and permissiveness of the imperial taxation regime which was a de facto land tax quotas system (Hase 2013: p. 34), which dated as late as the Ming Dynasty based on a system had not changed since 1300s (Huang 1981: p.61). The state did not bother or attempt to find out or survey unregistered tax land, which expanded not only due to population growth but also economic incentive provided by the perpetually fixed rent arrangement. This price theory analogy may be

\footnotetext{
${ }^{5}$ Yoo and Steckel (2010) did not consult the works of Rawski (1972), Hayes (1977), Kamm (1977), or Watson (1977), but that of Ka (1991), who based his work on his thesis (Ka 1987), and Ho $(1968,1975)$ whom Ka (1987) cited. Nor did Hase (2013), like Hayes (1977, 2006) or Kamm $(1977)$, refer to Ho $(1968,1975)$ or Ka $(1987,1991)$, although these two strings of literature covered the same subject and reinforced each other's points.
} 
useful: a lump sum charge for a buffet leaves the quantity of food unmetered; a fixed charge on land leaves its dimension unmeasured. A plot of rented land, in a sense, is like a poll tax on a rural landholder! The land bones holder bore the burden of paying the emperror land taxes and whether this provided an insurance against bad harvest for the holder of land skin rights so that the latter needed not face the county magistrate is something that worth further investigation. Under imperial Chinese examination system, a land bone holder as registered had the benefit of endorsement by the county magistrate for an application to obtain a quota place attend such examination. In order to get their sons onto the examination system, the land skin holder often had to buy a small piece of registered land from the land bone holder. From this extremely important finding of Hase (2013: pp. 42-49), one can infer that dood and steady payment of rent by the land skin holder would surely be a favourable consideration by the land bone holder.

Archival research showed that enforcement, inheritances and transactions of property rights in the absence of maps remained orderly and there was a land market for transacting two types of land rights.

This state of affairs persisted in Hong Kong, as part of Imperial China was settled and opened up for farming by those fleeing the Mongol invaders during the collapse of the Sung Dynasty in 1279, until 1898, when Britain leased a big swath of land called the New Territories for 99 years.

\section{Case Study 2: New territories Demarcation District lots in colonial and post-colonial Hong Kong}

As in the case of the Japanese changing the land tenure system in Taiwan after seizing the island from China (Yoo and Steckel 2010), the Colonial Hong Kong Government imposed on the New Territories the common law concept of fixed property and declared all land as belonging to the Crown and leased back to the occupiers for 99 years less three days. Those absentee owners of the rights to the bones of land, other than Wong Wai Chuk Tong, who owned the rights to the land bones of Cheung Chau, suffered a windfall loss, as they (for instance, those in Tung Chung) lost all rent claims - they were, in fact, dispossessed.

Given the high sensitivity to and skills of the British regarding law, that the colonial government chose to assign exclusive leasehold interests to the owners of land skin rights (i.e. the tenant $)^{6}$ and expropriate the land bone owners, a fact highlighted by Watson

\footnotetext{
${ }^{6}$ The exceptions were those who owned the land skins in Cheung Chau. The land bone owner was expropriated by legislation shortly before the return of Hong Kong to China on 1 July 1997.
} 
(1977), had to be a form of political quid pro quo to win the support of the residents of the New Territories so that they would be less willing to undertake anti-British activities.

A cadastral survey of settled land divided into 477 Demarcation Districts (DD) of about 200 acres each was efficiently conducted from 1899 to 1903 with the help of surveyors seconded from British India.

For each DD, a to-scale "Demarcation District Sheet" ("DD sheet") combining topographical and demarcation details on a scale of $\underline{1}$ to $\mathbf{1 9 8 0}$ with numbered lot holdings was drawn after the land was surveyed and a Block Crown Lease $(\mathrm{BCL})$ produced and issued in 1905. Note that the Japanese survey of Taiwan from 1898 to 1905 for the purpose of reforming land tenure in Taiwan occurred at about the same time the British Indian engineers surveyed Hong Kong and granted a BCL (Yoo and Steckel 2010).

The BCL came in the form of a written schedule of the name(s) of the owner(s) and the existing land use of each numbered lot within the DD. Each lot had a given area unless it was too small. All BCL and DD sheets could be inspected at the District Offices (the District Lands Offices since April 1982), which operated along the lines of the Imperial Chinese local magistrates combining executive and quasi-judicial functions.

The obvious objective of this comprehensive surveying and mapping exercise, after the British expropriated the land bone owners' interests, was to collect from the now royal lessees Crown rents and ease land resumptions for Crown purposes when required rather than to delineate private rural land boundaries for Chinese settlers to avoid disputes. Tax payments to the Crown signified a new political and economic allegiance and denied the owners their land bones. In terms of economic analysis, this expropriation of the absent land bone owners positioned the sitting tenants as the residual claimants (North 1977, 1990) , an institutional arrangement which is superior to the former system. The modern mind may reasonably expect that this comprehensive land surveying, mapping, and title registration exercise clarified the land boundaries once and for all and would be an excellent example of the need for the state provision of GIS information.

Yet, what has happened is that once land boundaries were delineated, the available mapping information became a potential dimension for litigation that was previously impossible. This potential was exploited during the early 1990s when rapid and intensive urbanization spilled over from Hong Kong's new towns to its farming hinterland and generated a string of court cases, which dwells on the exactitude of boundary lines, in the absence of any government boundary stones or survey markers which would only be used for leasehold land sold by the government. The legal battles were fought mainly in relation to actions for adverse possession, for which the developers were defendants. 
The court's help was sought, as the old system of District Officers, typically British officers who were erudite in Chinese literature and customs, acting as "parental officials" who could settle disputes as judges in consultation with the Chinese rural gentry class was replaced by a rational bureaucracy staffed by formally educated surveyors who were also District Lands Officers.

Some typical reasons for the disputes were the inconsistent boundaries of individual lots in the cadastral survey compared to the actual physical conditions of the lots; the thicknesses of the boundary lines on the DD sheets, which were drawn to a small-scale resulting in uncertainty over the exact boundaries by modern survey standards, which, in Hong Kong, must be geodetically correct and allow for an error margin of no more than 1-2 $\mathrm{cm}$ for ordinary land boundaries and for railway $\mathrm{mm}$. A retired principal government land surveyor explained that the DD sheet was only a form of "topological" representation of the land lots as if they were painted on the surface of a balloon and should be cautiously followed for accurate boundary identification purposes. Furthermore, as the DD Sheets were for the political purpose of Crown rent collection, any land parcel of one square foot to 436 square feet in area was recorded as " 0.01 acre".

One day before Britain relinquished Hong Kong to China, the colonial government passed an ordinance, The Land Survey Ordinance, requiring landowners to appoint qualified surveyors to generate government land survey data for their properties prior to development. This theoretically should, in the long run, eliminate all boundary issues mentioned above. The trouble, however, was that the post-colonial government opted to not verify or endorse the data provided by qualified persons, as required by law, and held that all such data were "for reference" only.

This non-committal attitude by the state clashed with its roles as a landlord and party to a contract, while the Block Crown Lease itself, like the Conditions of Sale for urban land, is a bona fide contract affirmed in Attorney General v. Tong Iu [1968] HCA 31/1968 (Davison 2004).

\section{Case Study 3: Subdivision of urban land by lessees}

All urban land parcels allocated by the Hong Kong Government through sale or grant are typically rectilinear and plotted by marker stones in the past and now by survey markers. Urban land parcels come from two distinct sources. The first is land on Hong Kong Island ceded by China to Britain in 1842 and on Kowloon peninsula to the south of Boundary Street and Stonecutter Island ceded by China in 1860. The second is land of the New Territories (i.e., all land to the north of Boundary Street and all other outlying islands), which were leased from China in 1898 . The second case is the setting for the second 
source of urban land parcels, which could have come from land resumed from the DD lot owners, but, more likely, came from new developable land formed by the government without bothering the landowners.

Regarding the first source of land, which was treated as the permanent property of the Crown, all pre-existing land bone or land skin interests were extinguished with some compensation.

For urban land parcels from any source, the colonial government started the land system anew free from former indigenous land interests. It clearly delineated land boundaries using marker stones and plans attached to the Conditions of Grant and/or Crown Leases. The boundaries of a plot set out will be re-measured upon development.

Strict prohibitions against partitioning land after sales and new legal requirements for land surveying prior to any approved subdivision means newly-granted urban lots and should be free from scrutiny. Yet, many old land parcels, ripe for redevelopment, have been infested by the problems of boundaries if a lessee subdivided his land into portions without accurate land surveying. The owners of the portions, upon redevelopment, may dispute the exact location of the boundaries, especially when the registered area of their portion entails longer boundaries than those that already exist.

Again, under the law, as in the above case, the landowner now needs to furnish professional survey data to the Survey and Mapping Office, which describes them as "for reference only." Disputes can only be settled by a judge.

\section{Discussion}

Three lessons of practical significance can be learnt from the case studies on disputes in relation to the precision of land boundaries of private land properties.

First, no boundary dispute can arise from the results of surveys in which no such results are obtained in the first place. This is not to say that the modern land surveyor creates a new problem, but that anything made available can be open to question and only suppressed by legislation. Even then, the matter still has to be adjudicated by the court if anyone disagrees with any statutorily proclaimed boundary.

Second, discounting purely emotional reasons, boundary disputes are only pertinent when exactitude in land boundaries matters because a development is boundary-related. 
Third, a technocratic bureaucracy may not reduce transaction costs, but may generate more, as its skills are oriented towards measurements, rather than towards conflict resolution.

Regarding Demsetz's (2011) paper, or the Third Coase Theorem, Case Study 1 showed that the absence of any mapping information did not matter when the cost of enforcement by the absentee landlord or the cost of what happened on the skin of the land was high. Disputes, then, were constrained to those in default of rent payment. For fiscal (taxation) purposes, unlike the case of legal cadasters, geodetic planimetric accuracy is secondary to the primary one for identifying the person responsible for paying taxes. The mere "general point-to-point" description of land "without specifying the bounds" in the mapless Imperial Chinese title deeds (Knapp 1980: p.63) described in Case Study 1 is a case in point. More importantly, Kent (1988) drew attention to the tendency of the British professional surveyor, as pointed out by Dale (1976), to be obsessed with extreme accuracy, a trait that may have to do with the self-image of the British surveyor, which Home (2006) described as "dedicated and upstanding servants of empire, applying higher-level mathematics to precise measurement, and managing field survey teams under often difficult conditions."7

Case Study 2 showed that in the old days, disputes over land boundaries in relation to the topologically correct, but less than precise, DD Sheets were efficiently settled by district officers who exercised a paternalistic and cost-effective jurisdiction like the old Imperial Chinese magistrates. When these archaic officials were replaced by formally-educated surveyors who were Weberian bureaucrats bent on measurements, the cost of enforcement actually escalated, as a new dimension of land that did not previously exist entered the picture: modern cadastral surveys. Arter (1960), a Surveyor General of Victoria, remarked that the preoccupation with over-precision "is a form of inverted superiority indoctrinated with an accuracy complex that goes far beyond the personal capacity and ability of the surveyor - and he knows it and it still persists." Advancements in precision tools since 1960 could have altered this view, but it is a reminder that precision needs to be commensurate with the purpose of a survey, which is contingent on technological limits.

\footnotetext{
${ }^{7}$ Kent's (1988) caution against the tendency to be pre-occupied with precision echoed the observation of his peer, Williamson (1984). Referring to Barrie (1977), Williamson (1984) wrote that, "surveying and charting is simply a matter of catching up with a relatively stable settlement pattern," although surveyors, often from a military or naval background, were involved in the laying out of towns in Australia's first settlements.
} 
In Case Study 1, the key determinants of land values were agrarian outputs while in Case Study 3 development intensity. Agrarian outputs are contingent on the labour and fertilizer inputs and land area rather than actual farm shape. Development intensities on the other than are sensitive to the actually locations and shape of sites in addition to mere area and hence precise measurement of the boundaries has become more and more important.

Both Case Studies 2 and 3 involved an element of political economy. In the history of the political economy of land surveying, two conclusions may be drawn. First, landlords generally do not favour detailed cadastral surveys imposed by the state. A classic example is their resistance in England to the national cadastral mapping proposal of 1836 (Kain 1975, 2002). While land, due to its permanence and immobility, is "readily identified, catalogued and taxed" (Kent 1988: p.99), along with being hard to hide (Ghatak 1975), determining who owns which plot of land is costly. The under-reporting of land holdings by owners and occupants of land to avoid taxation is a common and recurrent feature in China (Knapp 1980; Ka 1987; Smil 1999; Lin and Ho 2003; Hase 2013: p.36). De facto land use, while observable, may or may not be the same as de facto or de jure land ownership, as the transaction costs of correcting this can be prohibitively high. Second, in anticipation of the first, a new government established after a major constitutional change may, as in the case of the Norman conquest of England or Turkish control of Palestine (Kark 1997), or may not conduct a nationwide cadastral survey, as in the case of the Manchu conquest of China (Wang 1971). The absence of an Imperial cadastral survey had an element of winning rural support for the Manchu usurpers of the Han Chinese crown and the initiation of a comprehensive land survey of the "leased" New Territories, which resembled the survey for the compilation of the Domesday Book from 1085 to 1087 after the Norman conquest of England (Galbraith 1942), was for similar reasons. This was likely motivated by a major reallocation of property rights, which was intended to win political support for the British colonial Hong Kong government. Only new tax lords ${ }^{8}$ who intended to oust the Imperial Chinese fiscal influence (Japan in the case of Taiwan and Britain in the case of Hong Kong) for political, if not also economic, reasons conducted cadastral surveys and displaced the original tax collectors for the Manchu sovereign, who was the holder of rights to the land bones.

Case Study 3 was similar to 2 . Both called for an explanation of the legal anomaly of a landlord yielding his/her obligation to ascertain boundaries for lessees. One possible

\footnotetext{
${ }^{8}$ Taxation features in Kamm (1977), Chu and Lin (2001)) and Chun (1990) and was the central theme of Yang $(\mathbf{2 0 1 3}, \mathbf{2 0 1 4})$. However, they made no reference to mapping in tax collection.
} 
reason for this, informed by Coasian reasoning, is changes in transaction costs due to a constitutional transformation that came about in anticipation of de-colonization. Civil servants originally backed by a constitutionally autocratic colonial regime began to work under growing public criticism and demand for explanation of their conduct by elected politicians, who oddly do not run and hence become responsible for the government. They therefore strategically assigned the responsibility of determining the boundaries of urbanizing rural land to the lessees by legislation. This saves the transaction costs of administering public and political queries, if not also creates monopoly rent for interest groups.

The Third Coase Theorem applies to the dual or divided ownership of agricultural land in pre-colonial Hong Kong and pre-socialist Southern China. The absence of an initial government or a private cadastral survey of fields avoided the transaction costs of mapping and disputes over boundaries, in which fertility and land yields, at a time when the wilderness was ripe for clearance, were abundant and far more significant than the exactitude of land borders. Furthermore, this significantly reduced the transaction costs of governing a vast agrarian empire that was populated mostly by the Han ethnicity in Central and Southern China, but headed by the alien and minority Manchus from the southeastern end of Siberia, by not encroaching upon the "ordinary lives of folks" through the bureaucratic surveillance of private property. That would be an activity of the modern, rather than the pre-modern, state. Experts like Hayes (1977) and Watson (1977) considered the system admirably workable and effective. When the scenario, "the hills are tall and the Emperor far way" (i.e., the absence of dictatorial and centralist interferences by officials in the capital) prevailed, China was, more or less, prosperous and peaceful. This is a laissez faire reading into the Third Coase Theorem, which is in agreement with libertarian economics and small government politics. In fact, Ronald Coase, shortly before his death in September 2013, drew the attention of a group of visitors $^{9}$ to this Chinese proverb as a driving force of China's economy today mentioned in his book with Wang (Coase and Wang 2012).

The Third Coase Theorem also applies, albeit dynamically, to colonial and post-colonial agricultural land in the New Territories. The first British Indian cadastral survey of this land was intended to establish a new tax lord (the British Crown), which ousted the owners of land bone rights and conferred exclusive and undivided property rights to land skin rights holders (except for those on Cheung Chau). This produced Block Crown Leases with small scale DD Sheets. Such an initial clear delineation of lot boundaries was less an attempt to enforce tax payments, but rather to redirect the rents payable to the land

\footnotetext{
${ }^{9}$ Details to provide.
} 
bone holders by the colonial treasury to ensure their political allegiance. Subsequent disagreements over rights, if not settled by elderly village representatives, were resolved by "expatriate" Chinese-speaking British District Officers, which was the most efficient method of settling disputes, before they ended up in courts usually presided over by English-speaking judges. When a new demand for exactitude in land boundaries appeared during the 1960s for urban setting-outs and accelerated during the 1990s, mapping by land surveyors became necessary, despite the reluctance of the new technocratic surveyor of the District Lands Office, who took over the land matters from the District Officers. The court tends to fall back on the modern survey records kept by the District Land Office, as in the case of Ho Man Lap v. Ho King Kiu and Others [2013] $\mathrm{DCMP} / 2010$. These digital records comprise of a layer of data collected by the government technical land surveying staff and another layer reported by professional land surveyors hired by landowners under the Land Survey Ordinance. The government knows which set of data is its "own" and official and which is owned by "others," but is strictly required by law to be accurate as a personal liability of the land surveyor in practice. The survey record plans, kept and sold by the government to the public with copyright retained, however, do not reveal any distinction and always bear the bureaucratic caveat, "for reference only". However, these survey record plans are deemed by the court to be correct. Hong Kong's courts do not want to be bothered with fact-finding missions of a technical nature, which are for expert land surveyors. This is a sensible transaction cost reducing ruling.

The Third Coase Theorem applies well to the situation of subdividing urban land into small parcels and subsequent redevelopment by recombining plots or otherwise. The state was interested only in the initial delineation of the parent lots, but not their subsequent redelineations. This situation originally worked well, as evidenced by a rarity of disputes before the court between individual owners or between the government and owners. Hong Kong became more litigious as the government began to fully measure even the land subdivided privately, while developers have always sought to realise the maximum development potential of the lands they acquired. Disagreements sometimes happen between the state and individual owners. One typical source of dispute is that the land data, as recorded in the Land Registry, have inconsistencies. For instance, the actual area of a land plot measured by the government before it grants various development permissions, according to a privately-deposited plan, may be smaller than the recorded written figure, which the developer relies on to calculate its "plot ratio," which is the ratio between a building's gross floor area and gross site area. Such inconsistencies could be the results of human mistakes, technical errors, or even reasons for which records have been lost. The government has a choice: give the developer the benefit of the doubt or insist that one of the measures was a mistake. The former lowers transaction costs and 
the latter increases it. The typical government action is to pick the measure that achieves the lower gross floor area. So, if the site area recorded in writing is smaller than the area measured within the recorded boundary, the government would say the former prevails. However, if the latter figure is smaller, than it prevails. This approach is hardly defensible when based on logic or transaction costs. A better approach that can eliminate unnecessary litigation is when a plan always prevails for footprint delineation. If the recorded area is greater, than that should be used to determine a plot ratio. This would not adversely affect any other owner and was an attitude that prevailed under the colonial administration, but has since been lost. Once the development control technocrat, playing the role of emperor, imposes a manner of administration with a microscopic vision of development data, the extra transaction costs of enforcement and litigation, which hinder smooth redevelopment, are incurred. In a post-colonial political context in which neither political nor professional leadership has gained popular support, the technocratic development control apparatus would be subject to growing public pressure and complaints due to a mistrust of government officials in nearly all types of public service. Therefore, the court has to play an increasing role in resolving disputes, including those over land boundaries, as a last resort.

\section{Conclusion}

When two landlords dispute over the exact alignment of the common boundary between their properties, they may resolve the dispute violently or peacefully through private agreement through an arbiter they appoint or by litigation. When two tenants have a similar dispute, it is reasonable for them to expect the landlord to settle the matter upon request. However, interestingly, the post-colonial Hong Kong Government has appeared to derogate from this expected duty as the owner of virtually all the land in Hong Kong.

Under the rule of law, the court, acting in equity, is the de jure ultimate arbiter of any boundary dispute between two landlords. However, in jurisdictions in which the government is legitimate and powerful, the officialdom can be the de facto arbiter of any factual ambiguity in land boundaries, especially when the "landowners" are, in fact, lessees holding lands of the state, which is the landlord. The choice of the government as the arbiter is superior to relying on the court in this situation, as the government can act much faster than the court. However, as a government becomes more technocratic and loses effectiveness due to changes in its governance, the court will emerge as both the de facto and de jure final arbiter of disputes over land boundaries, even if the state owns all the land. 
Each case study has its idiosyncratic background of a major exogenous change ${ }^{10}$ in the political economy that shaped or reshaped the governance of the property rights delimitation in respect of land and in terms of land boundaries. That the Third Coase Theorem illuminated the three cases did not mean that the state was irrelevant. In fact, in the first case, the Manchu imperial government made a royal promise in 1713 to never raise land tax (Wang 1971; Hase 2013) and continued to use the pre-existing Ming customary law and records for land. This promise was faithfully honoured. In the second case, the British colonial government abolished in the leased Chinese territory (other than Cheung Chau) the rights of land bone owners and replaced the customary land law with common law. Then it provided written land survey information to owners of the land rights, as well as to the general public. In the third case, the colonial government allocated leasehold interests through sales with clear boundary delineations, although new boundaries created by the private subdivision of land remained an area of ambiguous de facto property rights. The professional land surveyor has been pivotal in resolving such factual ambiguities.

This paper showed how Demsetz's recent (2011) reflections on Coase's Theorem focused attention on property rights delimitation under the Third Coase Theorem in relation to how land boundary delineation under specific situations was or was not significant. When land is treated as an input for a chattel that is no longer fixed to land, area measurement is more important than boundary-fixing. When land becomes valued for its location and fixtures, especially when the form of the fixtures depends on the exact alignment of the boundary, as in the case of real estate development under government regulations, meticulous boundary delineations and disputes over the geodetic (Bannister et al 1998) precision of cadastral surveys for such delineations emerge and incur high transaction costs. Therefore, land surveying becomes highly significant.

The Coasian concept of "clearly defined property rights," like the legal concept of "certainty" in a contract, is constrained by technology due to positive transaction costs. This means that neither requires full information, something that is always regressing into the future. As time goes by, surveying techniques sharpen and boundary-determined real estate values grow. Hence, geodetically-precise boundary delineation becomes essential in property development. This transformation of boundaries described by memory, words, and "metes and bounds" (wooden stakes/boundary stones) into those delineated by geodetically precise lines involves the co-evolution of technological innovations in

10 This means our analysis is Coasian, as property rights in the Coasian world are exogenous policy variables. North's analysis is endogenous (North and Thomas 1973, North 1990). 
surveying and mapping; growth in the value of land as real estate; and depersonalization ${ }^{11}$ in the protection, enforcement, and transactions of land property in which the modern impersonal state has much involvement. This view connects well with the critical view of mapping as 'performance' by Senel (2014), who reminds us that the planimetrically correct map is, in a sense, a distorted representation of reality. The better view, however, is that a map is a sign and part of a sign production process in real estate development (Lai et al 2014) which points to something else. Transaction costs in Coasian analysis, unlike what Demsetz (2011: p.7) interpreted, are by definition not part of the production cost or else it could have been easily modelled as part of the neoclassical production function. They explain, thanks to the Third Coase Theorem, why less than perfectly defined property boundaries are adequate under different institutional arranagements, an important point credited to Demsetz.

\section{Acknowledgements}

The authors acknowledge the useful comments and advice by two Referees and Cheung's (2013) useful information on land surveying in Hong Kong brought to their attention by Dr. Ken Ching, Chartered Land Surveyor.

${ }^{11}$ Imperial Roman land law gradually moved from one based on a personal to a territorial understanding (see Castellino and Allen 2003: p.40). 


\section{REFERENCES}

\section{Court Cases}

Attorney General v. Tong Iu [1968] HCA 31/1968.

Wibberley v. Insley [1999] HL15.

Lam Pak Kau v. Yu Yuet Fat [1999] CACV 205/1999.

Black v. Norris and Registrar General of Land Titles, [2012] NBQB 346.

Ho Man Lap v. Ho King Kiu and Others [2013] DCMP/2010.

Yip Kwok Sun v. Poly-style Limited [2013] HKCU 2523 HKDC 31/10/2013 Hong Kong Cases Unreported Case.

\section{References}

Allen, Douglas W. "Homesteading and property rights or 'how the West was really won?'” Journal of Law and Economics 34, No.1 (1991), pp.1-23.

Arter, F.W. "A Review of the Torrens System and Some Aspects of Title Survey" Australian Surveyor June (1960): 108-118.

Bannister, Arthur, Stanley Raymond, and Raymond Baker. Surveying, $7^{\text {th }}$ ed., Harlow, Longman, 1998.

Barrie, J.K. "Land registration and boundary surveys," Australian Surveyor 28, No.5 (1977): pp.256-262.

Blomley, Nicholas. "Law, property, and the geography of violence: the frontier, the survey, and the grid." Annals of the Association of American Geographers 93, No.1 (2003): pp.121-141.

Brock, John J.F. "The great wall of China: the world's greatest boundary monument," International Federation of Surveyors (June 2014): pp.1-13.

Butts, George F. Foreword to Donald A. Wilson. Interpreting Land Records. Hoboken, John Wiley and Sons, 2006, pp.vii-viii.

Castellino Joshua and Steve Allen (eds.) Title to Territory in International Law: A Temporal Analysis, Aldershot, Hampshire, Ashgate, 2003. 
Clarke, Donald. "China's stealth urban land revolution," American Journal of Comparative Law 62 (2014): pp.323-366.

Clay, Karen, and Gavin Wright. "Order without law? Property rights during the California gold rush," Explorations in Economic History 42, No.2 (2005): pp.155-183.

Cheung, Edmond. Hong Kong Land Surveyors WordPress Selected Articles, Hong Kong: WordPress, 2013.https://hklandsurveyor.wordpress.com/2013/06/27/a-compilation-ofblog-posts/

Cheung, Steven N.S. (1969), The Theory of Share Tenancy. Chicago, University of Chicago Press.

Cheung, Steven N.S. "On the new institutional economics," paper delivered at the Nobel Symposium, Stockholm, August 17-20, 1990.

Chu, Yun-han and Jih-wen Lin. "Political Development in 20th-Century Taiwan: StateBuilding, Regime Transformation and the Construction of National Identity," The China Quarterly, 165 (2001): pp.102-129.

Chun, Allen. "Policing society: the 'rational' practice of British colonial land administration in the New Territories of Hong Kong c. 1900," Journal of Historical Sociology 3, No.4 (1990): pp.401-422.

Coase, Ronald Harry. “The nature of the firm," Economica. 4 (1937): pp.386-405

Coase, Ronald Harry. "The Federal Communications Commission," Journal of Law and Economics 2 (1959): pp.1-40.

Coase, Ronald Harry. "The problem of social cost," Journal of Law and Economics 3 (1960): pp.1-44.

Coase, Ronald Harry. The Firm, the Market and the Law. Chicago, University of Chicago Press, 1988.

Coase, Ronald Harry and Ning Wang. How China Became Capitalist. Palgrave Macmillan, 2012.

Dale, P.F. Cadastral Surveys within the Commonwealth, Overseas Research Publication No.23, London, HMSO.

Davison, John. "A lawyer's perspective on New Territories land tenure" Hong Kong Surveyor (now Surveying and Built Environment) 15, No.2 (December 2004): pp.75-85. 
Dawkins, Jeremy. "“Fast Forward" needs a property market, supported by an independent planning system." Paper presented to the $48^{\text {th }}$ ISOCARP Congress 2012 , Perm, Russia, from 10-13 September 2012.

Demsetz, Harold. "The problem of social cost: What problem? A critique of the reasoning of A.C. Pigou and R.H. Coase," Review of Law and Economics 7, No. 1 (2011): pp. 1-13.

de Rijcke, Izaak. "Black v. Norris: A new synopsis of survey Law," Geomatica 67, No.1 (2013a): pp.31-54.

de Rijcke, Izaak. "Geomatics and the law: The geomatics professional in court: A crisis in non-confidence?" Geomatica 67, No.4 (2013b): pp.276-279.

Ekbäck, Peter. "Private, common, and open access property rights in land--An investigation of economic principles and legislation." Nordic Journal of Surveying and Real Estate Research 6, No.2 (2009): pp.57-74.

Elman, Benjamin A. "The Jesuit role as "experts" in High Qing cartography and technology," National Taiwan University History Bulletin. Taida lishi xuebao (2003): pp.223-250.

Galbraith, V.H. "The making of Domesday Book," English Historical Review 57, No.226 (1942): pp.161-177.

Ghatak, Subrarata. "Marketed surplus in Indian agriculture: theory and practice," Oxford Bulletin of Economics and Statistics 37, No.2 (1975): pp.143-153.

Hayek, F.A. The Road to Serfdom. Chicago, University of Chicago, 1944.

Hayes, James. The Hong Kong Region 1850-1911: Institutions and Leadership in Town and Countryside, Archon books, Hamden, Connecticut, 1977.

Hayes, James H. The Great Difference: Hong Kong's New Territories and Its People 19892004. Hong Kong, Hong Kong University Press, 2006.

Hase, Patrick H. Custom, Land and Livelihood in Rural South China, Hong Kong, Hong Kong University Press, 2013.

Hallagan, W.S. "Share Contracting for California Gold," Explorations in Economic History 15, No.2, (1978): pp.196-210.

Havel, Małgorzata Barbara. "Delineation of property rights as institutional foundations for urban land markets in transition." Land Use Policy 38 (2014): pp.615-626. 
Hazard, Geoffrey C. Jr., "Authority in the dock," Boston University Law Review 69 (1989): pp.469-476.

Hedquist, Bruce. "On the history of land surveying in China," Surveying and Mapping 35 (1975): pp.251-254.

Ho, Samuel Pao-San. "Agricultural Transformation Under Colonialism: The Case of Taiwan," Journal of Economic History 28, No.3 (1968): pp.313-340.

Ho, Samuel Pao-San. "The Economic Development of Colonial Taiwan: Evidence and Interpretation," Journal of Asian Studies 34, No.2 (1975): pp.417-439.

Home, Robert. "Scientific survey and land settlement in British colonialism, with particular reference to land tenure reform in the Middle East 1920-50," Planning Perspectives 21, No.1 (2006): pp.1-22.

Huang, R. 1587: A Year of No Sifnificance: the Ming Dynasty in Decline, New Haven, Yale University Press, 1981.

Ka, Chih-ming. Land Tenure, Development and Dependency in Colonial Taiwan, 18951945. PhD Thesis, State University of New York at Binghamton, 1987.

Ka, Chih-ming. "Agrarian Development, Family Farms and Sugar Capital in Colonial Taiwan, 1895-1945," Journal of Peasant Studies 18, No.2 (1991): pp.206-240.

Kain, Roger J.P. "R.K. Dawson's proposal in 1836 for a cadastral survey of England and Wales," The Cartographic Journal 12, No.2 (1975): pp.81-88.

Kain, Roger J.P. and Elizabeth Baigent. The Cadastral Map in the Service of the State: A History of Property Mapping. Chicago, University of Chicago Press, 1992.

Kain, Roger J.P. "The role of cadastral surveys and maps in land settlement from England," Landscape Research 27, No.1 (2002): pp.11-24.

Kamm, John Thomas. "Two essays on the Ching economy of Hsin-an, Kuangtung", Journal of the Royal Asiatic Society Hong Kong Branch 17 (1977): 55-84.

Kark, Ruth. "Mamlūk and Ottoman cadastral surveys and early mapping of landed properties in Palestine," Agricultural History 71, No.1 (1997): pp.46-70.

Kent, Robert B. "Property tax administration in developing countries: alternatives for land registration and cadastral mapping," Public Administration and Development 8 (No.1): pp.99-113. 
Kinda, Akihiro. "Some traditions and methodologies of Japanese historical geography," Journal of Historical Geography 23, No.1 (1997): pp.62-75.

Knapp, Ronald G. "Settlement and frontier land tenure", in Ronald G. Knapp (ed.). China's Island Frontier: Studies in Historical Geography of Taiwan, Honolulu, University Press of Hawaii, 1980, pp.55-68.

Kreiken, Floris, and David Koepsell. "Coase and Copyright," Journal of Law, Technology and Policy 2013, No.1 (2013): pp.1-44.

Lai, Lawrence W.C. Zoning and Property Rights: a Hong Kong Case Study. Hong Kong, Hong Kong University Press, 1998.

Lai, Lawrence W.C. "The problem of social cost': the Coase Theorem and externality explained: Using simple diagrams and examples to illustrate the role of land use planning in tackling externalities" Town Planning Review 78, No.3 (2007): pp.335-368.

Lai, Lawrence W.C. "'Where to draw the line?' That is a land use planning question for the land surveyor and the town planner," Land Use Policy 42 (2015): pp.619-627.

Lai, Lawrence W.C. and Frank T. Lorne. "“Ambiguous property rights: A taxonomic and exploratory account of post-colonial rural housing in Chinese Hong Kong," Urban Studies 51, No.10 (2014a): pp.2052-2067.

Lai, L.W.C. and Frank T. Lorne. "Transaction Cost Reduction and Innovations for Spontaneous Cities: Promoting a "Meeting" between Coase and Schumpeter," Planning Theory 13, No.2 (2014b): pp. 170-188.

Lai, Lawrence W.C., Kwong Wing Chau, Chester K.K. Lee and Frank T. Lorne. "The informational dimension of real estate development: a case of a "positive noninterventionist" application of the Coase Theorem." Land Use Policy Vol.41 (2014): pp. 225-232.

League of Nations (1928) Island of Palma Case (Netherlands v. USA). 4 April 1928, Reports of International Arbitral Awards, Volume II, pp.829-871.

La Croix, Sumner J. "Property rights and institutional change during Australia's gold rush," Explorations in Economic History 29, No.2 (1992): pp.204-227.

Li, Lixing. "Land titling in China: Chengdu experiment and its consequences," China Economic Journal 5, No.1 (2012): pp.47-64. 
Libecap, Gary D. "Property rights in economic history: implications for research," Explorations in Economic History 23, No.3 (1986): pp.227-252.

Libecap, Gary D. and Dean Lueck. "Land demarcation systems," from Research Handbooks

In Law and Economics, Ed. Kenneth Ayotte and Henry E. Smith, Ch.13, Massachusetts, Edward Elgar, 2011, pp.257-294.

Lin, George, and Samuel P.S. Ho. "China's land resources and land-use change: insights from the 1996 land survey," Land Use Policy 20, No.2 (2003): pp.87-107.

McDowell, Andrea G. "From commons to claims: property rights in the California gold rush," Yale Journal of law and Humanities 14, No.1 (2002): pp.1-72.

Navratil, Gerhard. “Modeling data quality with possibility distributions,” na, 2009.

North, Douglass C. "Markets and other allocation systems in history: the challenge of Karl Polanyi." Journal of European Economic History 6, no. 3 (1977): pp. 703-716.

North, Douglass C. Institutions, Institutional Change and Economic Performance, Cambridge, Cambridge University Press, 1990.

North, Douglass C. and Robert Thomas. The Rise of the Western World: a New Economic History, Cambridge, Cambridge University Press, 1973.

Palmer, Michael J.E. "The surface-subsoil form of divided ownership in late Imperial China: Some examples from the New Territories of Hong Kong," Modern Asian Studies 21, No.1 (1987): pp.1-119.

Pottage, Alain. "The measure of land," The Modern Law Review 57, No.3 (May 1994): pp.361-384.

Ramseyer, J. Mark. "The fable of land reform: expropriation and redistribution in occupied Japan," Available at SSRN 2166688 (2012).

Rose-Redwood, Reuben Skye. "The surveyor's model of the World: The uses and abuses of history in introductory surveying textbooks," Cartographica 39, No.4 (2004): pp.45-54.

Rawski, Evelyn Sakakida. Agricultural Change and the Peasant Economy of South China. Cambridge: Harvard University Press, 1972.

Rushworth, W.D., and W.P. Smith. "Mapping and demarcation for the Argentine-Chile frontier case," The Photogrammetric Record 6, No.32 (1968): pp.150-167. 
Senel, Aslihan. "Mapping as performing place." disClosure: A Journal of Social Theory 23, no. 1 (2014): pp. 91-119.

Smil, Vaclav. "China's agricultural land," The China Quarterly 158 (1999): pp.414-429.

Swetz, Frank J. "Surveying," in Helaine Selin ed. Encyclopaedia of the History of Science, Technology, and Medicine in Non-Western Cultures, Berlin, Springer, 2008, pp.20632067.

Umbeck, John. "A theory of contract choice and the California gold rush," Journal of Law and Economics 20, No.2 (1977a): pp.421-437.

Umbeck, J. "The California Gold Rush: A Study of Emerging Property Rights," Explorations in Economic History 14, No.3 (1977b), pp.197-226.

Umbeck, John. "Might makes rights: A theory of the formation and initial distribution of property rights" Economic Inquiry 19, No.1 (1981): pp.38-59.

Wang, Yeh-Chien. "The fiscal importance of the land tax during the Ch'ing Period," Journal of Asian Studies 30, No.4 (1971): pp.829-842.

Watson, James L. "Hereditary tenancy and corporate landlordism in traditional China: A case study," Modern Asian Studies 11, No.2 (1977): pp.161-182.

Willamson, I.P. "The development of the cadastral system in New South Wales" Australian Surveyor 32, No. 1 (1984): 2-20.

Yang, He. "Land and peasants in late Imperial China: An economic analysis," PhD dissertation, George Mason University, 2013.

Yang, Helen He. "Dual landownership as tax shelter: An economic analysis of perpetual lease", unpublished manuscript, Xiamen University, July 31, 2014. Date of access: 10 December 2014.

Yoo, Dongwoo and Richard Steckel. "Property rights and financial development: The legacy of Japanese colonial institutions," NBER Working Paper 16551, NBER, Cambridge, MA, 2010. 